Pak. J. Agri., Agril. Engg., Vet. Sci., 2020, 36 (1): 21-26

ISSN: 1023-1072 (Print), ISSN: 2663-7863 (Online)

https://doi.org/10.47432/pjaaevs.2020.36.1.4

\title{
RESPONSE AND ACCLIMATIZATION OF INTRODUCED JUJUBE (ZIZIPHUS MAURITIANA) VARIETY FOR THE UPLIFT OF SOCIO-ECONOMIC CONDITIONS AT DESERT AREA OF THARPARKAR, SINDH, PAKISTAN
}

\author{
A. K. Pathan, M. S. Depar, M. W. Kalroo, I. A. Rajput and R. Ahmed \\ PARC-Arid Zone Research Institute, Umerkot, Sindh, Pakistan
}

\begin{abstract}
Current study was carried out for adaptability and response of newly introduced jujube (Ziziphus mauritiana) variety in desert area of district Umerkot, Sindh with poor quality groundwater ( $>3500 \mathrm{ppm}$ TSS). Aim of the study was to acclimatize this variety under harsh conditions to uplift the socioeconomic situation of local population. The study was carried out for five consecutive fruiting seasons viz. flowering and fruiting season 2013-2014 to 2017-2018. The results revealed that during first fruiting season 2014-15, there were only three branches plant ${ }^{-1}, 154$ to 239 fruits branch ${ }^{-1}, 462$ to 879 fruits plant $^{-1}, 25.5$ to $46.7 \mathrm{~g}$ fruit weight, 8.4 to $9.2 \mathrm{~mm}$ fruit size, 4.1 to $7.7 \mathrm{~kg}$ fruit yield plant ${ }^{-1}$ and 442.8 to $831.6 \mathrm{~kg}$ fruit yield $\mathrm{acre}^{-1}$. But from the third year to onwards i.e from 2015 to 2018 a continuous increase was observed for all characters studied like number of branches plant ${ }^{-1}$ increased from 5 to 8 , number of fruits branch ${ }^{-1}$ increased from 339 to 375 , total fruits plant ${ }^{-1}$ increased from 1695 to 2538 , weight of fruit was increased from 58.6 to $107.15 \mathrm{~g}$, size of fruit increased from 9.2 to $9.8 \mathrm{~mm}$, yield plant $^{-1}$ was increased from 11.0 to $31.45 \mathrm{~kg}$, yield acre ${ }^{-1}$ was increased from 1188 to $3396 \mathrm{~kg}$ and water use efficiency increased from 2.7 to $10.6 \mathrm{~kg} \mathrm{~m}^{3}$. Considering the above results, it was concluded that Ziziphus fruit yield, weight and size increases from third year to onwards significantly on brackish water and soil of arid areas of Thar. Pruning each year after fruit harvesting was found to be essential. As this plant with stands in harsh climate of Thar desert successfully, so it provides food in the form of fruits, fodder through leaves and wood for fuel and shelter for humans and animals, thus it will be helpful to the people of Thar in terms of malnutrition, food scarcity and climate change, as well.
\end{abstract}

Keywords: growth and yield, malnutrition, Tharparkar, Ziziphus mauritiana

\section{INTRODUCTION}

Jujube locally called Ber (Ziziphus mauritiana L.) is one of the important and ancient fruit trees of arid and semi-arid region of the world and is considered as a hardy specie against extreme drought situations (Nizamani et al., 2015). Genus Ziziphus is considered as multipurpose crop of the region (Davis et al., 2006). Ber is cultivated in Indo-Pak sub-continent as a fruit (Mushtaq et al., 2003), fuelwood, fodder (Luna, 1996) and also as windbreak (Sarwar, 2006). $Z$. mauritiana is a commercially important species of Pakistan (Mabberley, 1997). Jujube fruit is considered to be one of the nutritious fruit of the world (Nizamani et al., 2015) and is also named as "Poor's Apple" (Singh and Batnaar, 2019). Fruits of jujube are used in variety of ways i.e., consumed as fresh and also dehydrated for later use. Its by-products are easily available and include pickles, chutnies, moraba, juices and

*Corresponding author: ranaimran234@gmail.com candies. It is rich in vitamins like vitamin C, riboflavin and thiamine, minerals like potassium, phosphorus, manganese and calcium and other important elements like sodium, zinc, iron and copper (Chowdary and Padashetty, 2000). The vitamin and mineral substance of the fruit help to support cardiovascular health and raise the metabolism (Hoque, 2002). In addition, extracts from fruits, seeds, leaves, stems and bark are applied in many traditional medications to relieve the effects of insomnia, skin diseases, inflammation and fever (Islam, 2005). Jujube leaves also play vital role as a fodder to feed livestock (sheep, goat and cattle) in some countries and its tough wood is used for fuel purpose (Bajwa et al., 1972). In many regions, Ziziphus is grown as a hedge due to their spines which create effective live-fencing (Rahman et al., 2007).

The global warming is increasing due to current issue of climate change and changed the pattern of rainfall. Due to these climatic factors 
malnutrition becomes the major issue in areas particularly where the food availability is limited. Desert regions of southern Sindh, especially some areas of Umerkot and Tharparkar districts are at the risk of climate change, where the people facing issues of food scarcity, hunger and malnutrition. Fruit plant like Ziziphus has the ability to tolerate extreme droughts and withstand on brackish underground water (Jat et al., 2004; Azam et al., 2006). There are many grafted varieties of jujube that are under cultivation in different irrigated areas of Sindh which includes Soofi, Kheerol (Chambeli), Sanghri, Gola and Dehli Gola. The Gola seems to be the variety included in this study is most popular variety which has two types, the Green leemai and the Golden white (Khushk et al., 2013).

The objectives of our study were to evaluate the growth and fruiting response of Dehli Gola variety of ber at arid region and to find out the quality of fruit and yield on brackish water with more than 3500 ppm salt level at arid area of Umerkot.

\section{MATERIALS AND METHODS}

This study was carried out at the PARC-Arid Zone Research Institute, Umerkot Sindh from
2013 to 2018. The ber variety Dehli Gola was included in the current study. Irrigation was applied through drip irrigation system with brackish water having salt concentrations of more than $3500 \mathrm{ppm}$. The data of growth, fruit yield and quality parameters on average i.e., number of branches plant ${ }^{-1}$, number of fruits branch $^{-1}$, number of fruits plant ${ }^{-1}$, fruit weight $(\mathrm{g})$, fruit size $(\mathrm{mm})$, fruit yield plant ${ }^{-1}(\mathrm{~kg})$ and fruit yield acre $^{-1}(\mathrm{~kg})$ were recorded. Five trees having uniform size and approximately same age constituted the unit of replication. Data on number of branches plant $^{-1}$ was computed by counting number of branches from five randomly selected trees. Number of fruits branch ${ }^{-1}$ and total fruits plant $^{-1}$ were computed by counting their numbers. Weight of fruit $(\mathrm{g})$ was calculated by taking weight of 100 fruits from each plant. Size of fruit $(\mathrm{mm})$ was calculated with the help of Vernier calipers. Fruit yield plant $^{-1}(\mathrm{~kg})$ was determined by weighing total fruit yield collected from initial harvesting till last harvest from selected plants, whereas fruit yield acre ${ }^{-1}(\mathrm{~kg})$ was calculated by using formula from fruit yield plant $^{-1}$. Plant data was subjected to Analysis of Variance (ANOVA), Using Statistics V.8.1 Model.

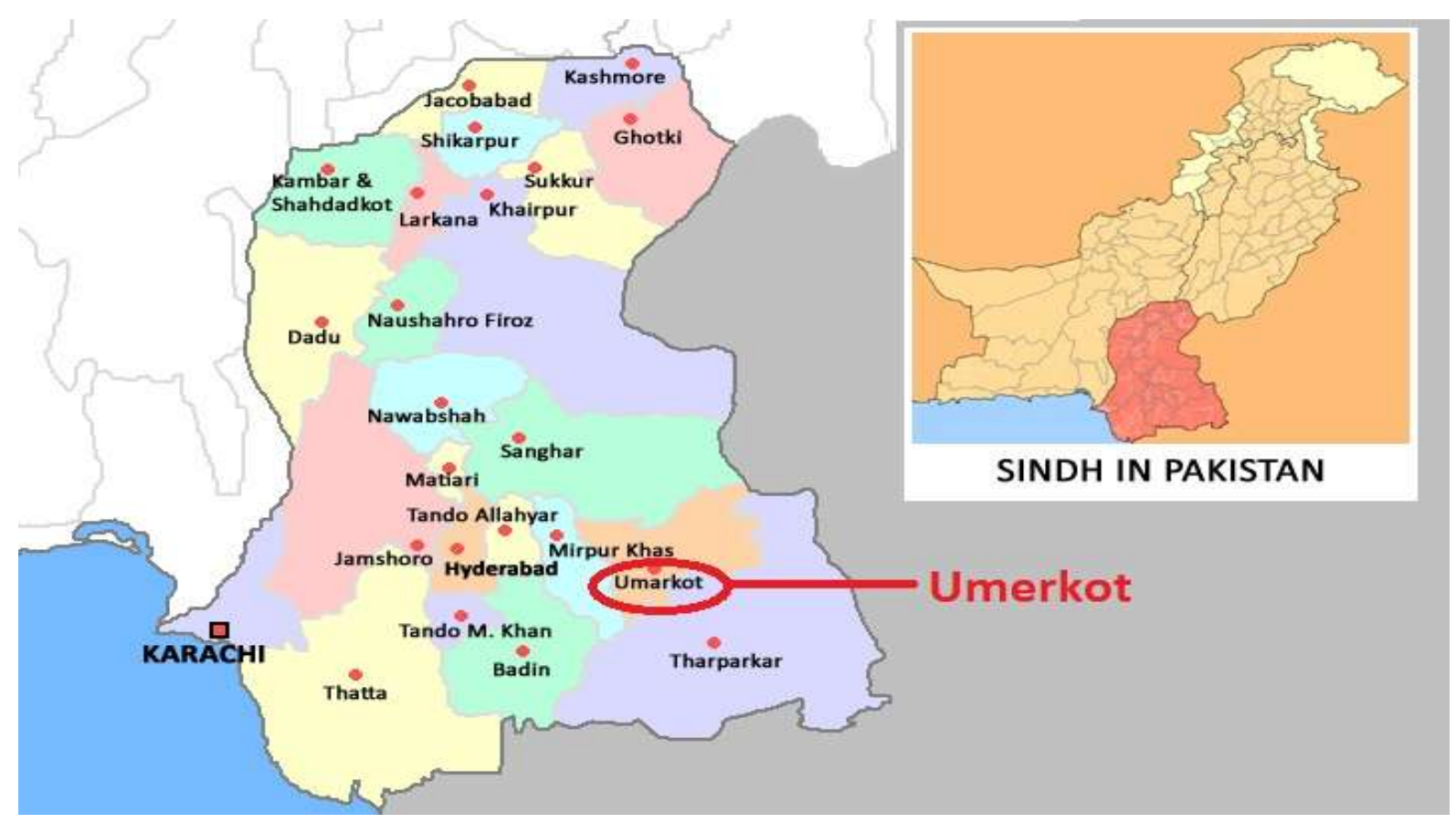

Map of Sindh showing location of the study (Umerkot) 

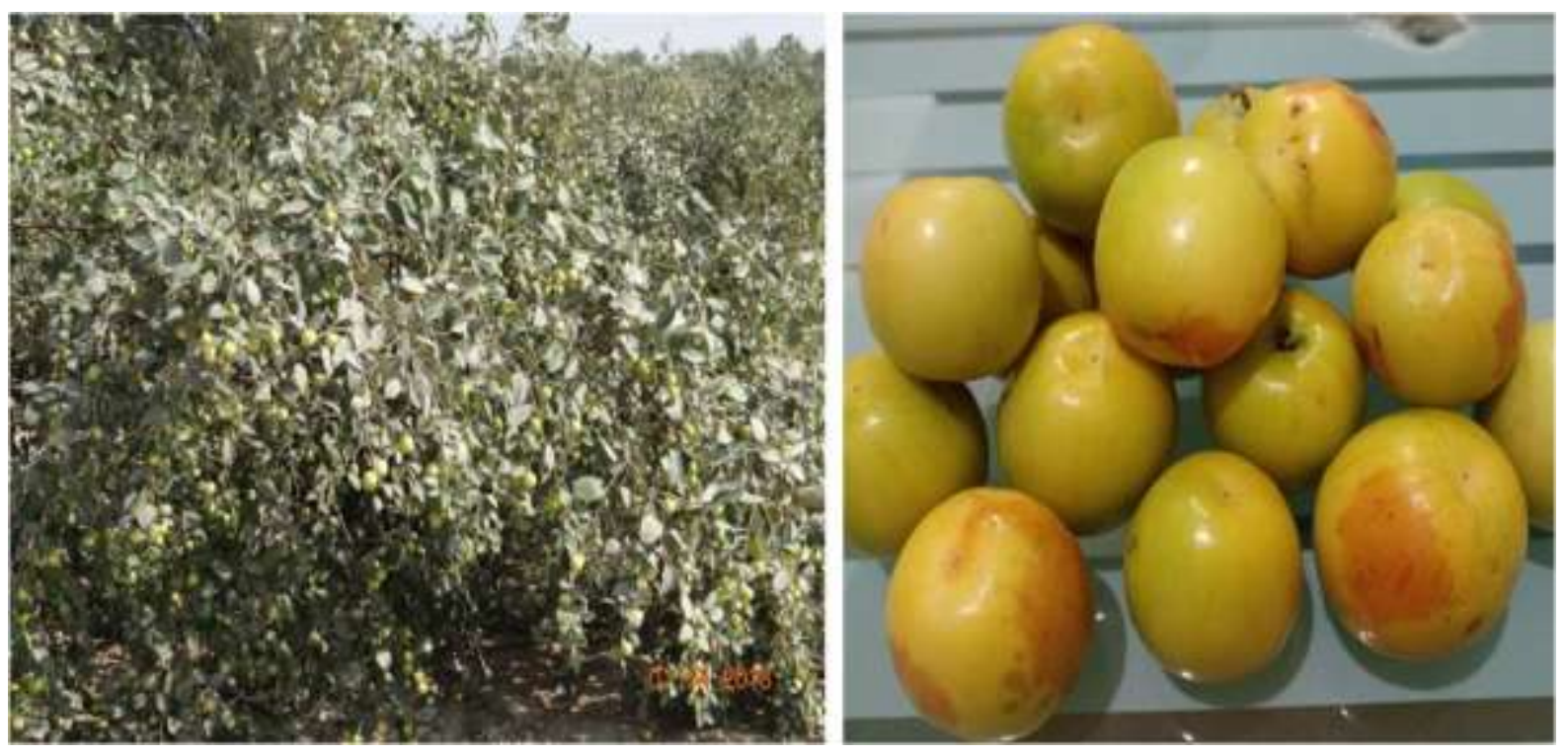

Plate 1. Ber trees and fruit at PARC-AZRI, Umerkot, Pakistan

\section{RESULTS}

The results revealed that there was significant $(P<0.01)$ difference among the fruiting years for number of branches plant ${ }^{-1}$, number of fruits branch $^{-1}$, total fruits plant ${ }^{-1}$; weight $(\mathrm{g})$, size $(\mathrm{mm})$ and fruit yield plant ${ }^{-1}$ and $\operatorname{acre}^{-1}(\mathrm{~kg})$. The jujube plants were planted in 2012, hence the morphological data recording was initiated from 2013-14. Five years consecutive data, indicate that mean main branches were counted as 4 branches plant ${ }^{-1}$ in 2013-14. Maximum main branches plant $^{-1}$ were found in $5^{\text {th }}$ fruiting seasons (Figure 1a). Fruit size is an important attribute that contributed towards yield. Maximum fruit size was recorded in year 2017$18(44.5 \mathrm{~mm})$, followed by $2015-16(43.6 \mathrm{~mm})$. While minimum fruit size was observed during 2014-15 that was calculated as $38.7 \mathrm{~mm}$ (Figure 1b).

Number of fruits plant $^{-1}$ is an important attribute that contributes towards yield. Five year data for number of fruits plant ${ }^{-1}$ is presented in Figure 1c. Maximum number of fruits plant $^{-1}$ was found in fruiting year 2017-18 (2455 fruits plant $^{-1}$ ), followed by 2016-17 (1833 fruits plant ${ }^{-1}$ ), while minimum number of fruits plant ${ }^{-1}$ was recorded in first fruiting season (2013-14) that was 462 fruits plant $^{-1}$. Single fruit weight is a major contributor towards overall plant yield. Maximum single fruit weight was computed in fruiting year 2017-18 (30.15 g), followed by 2015-16 (28.6 g), while minimum single fruit weight was observed in 2016-17 that was $25.5 \mathrm{~g}$ (Figure 1d). (a)

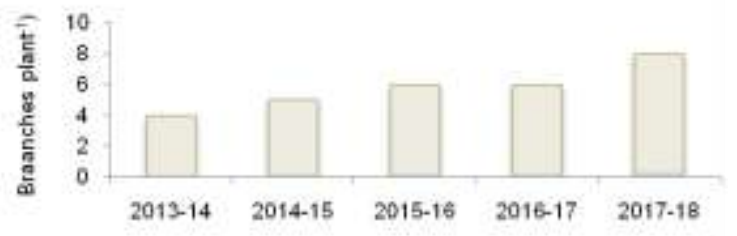

(b)

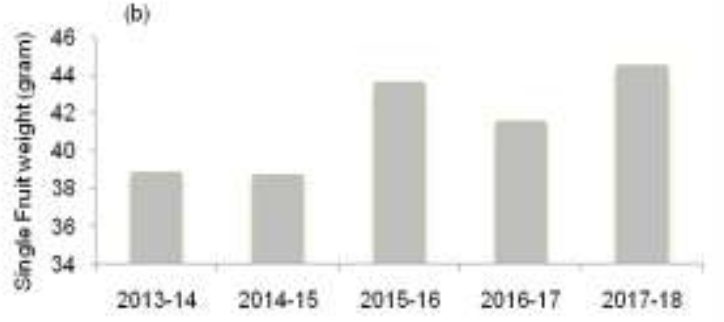

(c)

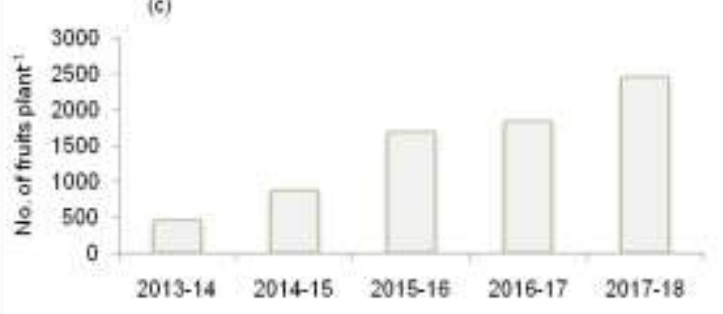




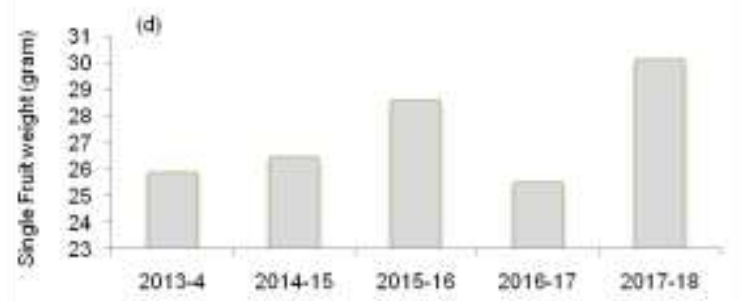

Figure 1. Fruiting characteristics of Gola ber variety, (a) Number of main branches/plant (b) Fruit size, (c) Number of fruits/plant and (d) single fruit weight

Yield is one of the important economic attribute towards economic value for growers. Fruit yield (plant ${ }^{-1}$ and acre $^{-1}$ ) is presented in Figure 2 for five fruiting seasons. There was increasing trend in fruit yield starting from fruiting season 2013-14 as lowest yield to maximum yield in year 2017-18. Maximum yield plant ${ }^{-1}$ was observed as $55.66 \mathrm{~kg} \mathrm{plant}^{-1}$ (2017-18), followed by $44.95 \mathrm{~kg} \mathrm{plant}^{-1}(2016-17)$ as indicated in Figure 2a. Maximum fruit yield acre $^{-1}$ was recorded in year 2017-18 $(6191.28 \mathrm{~kg})$, followed by $4342.6 \mathrm{~kg} \mathrm{acre}^{-1}$ in 2016-17 (Figure 2b.).
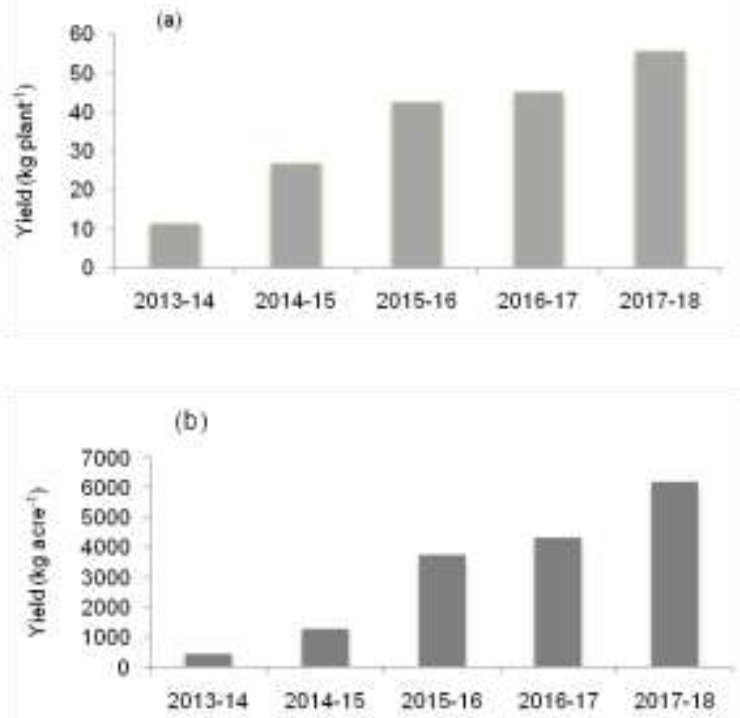

Figure 2. Yield characteristics of Gola ber variety (a) Fruit yield per plant (b) Fruit yield per acre

\section{Meteorological parameters}

The meteorological data for 2014, 2015 and 2016 are presented in Figure 3. Mean maximum temperature for these three years was almost same except for 2016 (Figure 3a). In 2016 mean maximum temperature was found higher as compared to 2014 and 2015 (Figure 3b). Relative humidity was also observed similar for all three years from available data (Figure 3c and d) with slight fluctuations of relative humidity percentage in the months January, July and August (Figure 3d).

As for as pattern of precipitation (rainfall) is concerned, change in pattern of precipitation was observed from June to November that is peak in vegetative and afterward flowering and fruiting time during three years $(2014,2015$ and 2016). During 2014, 2015 and 2016 variation was found in precipitation particularly from JuneNovember, whereas the maximum variation in precipitation was observed in month of July for the year 2015 in which precipitation was increased to $400 \mathrm{~mm}$ in a single month (Figure 3e).
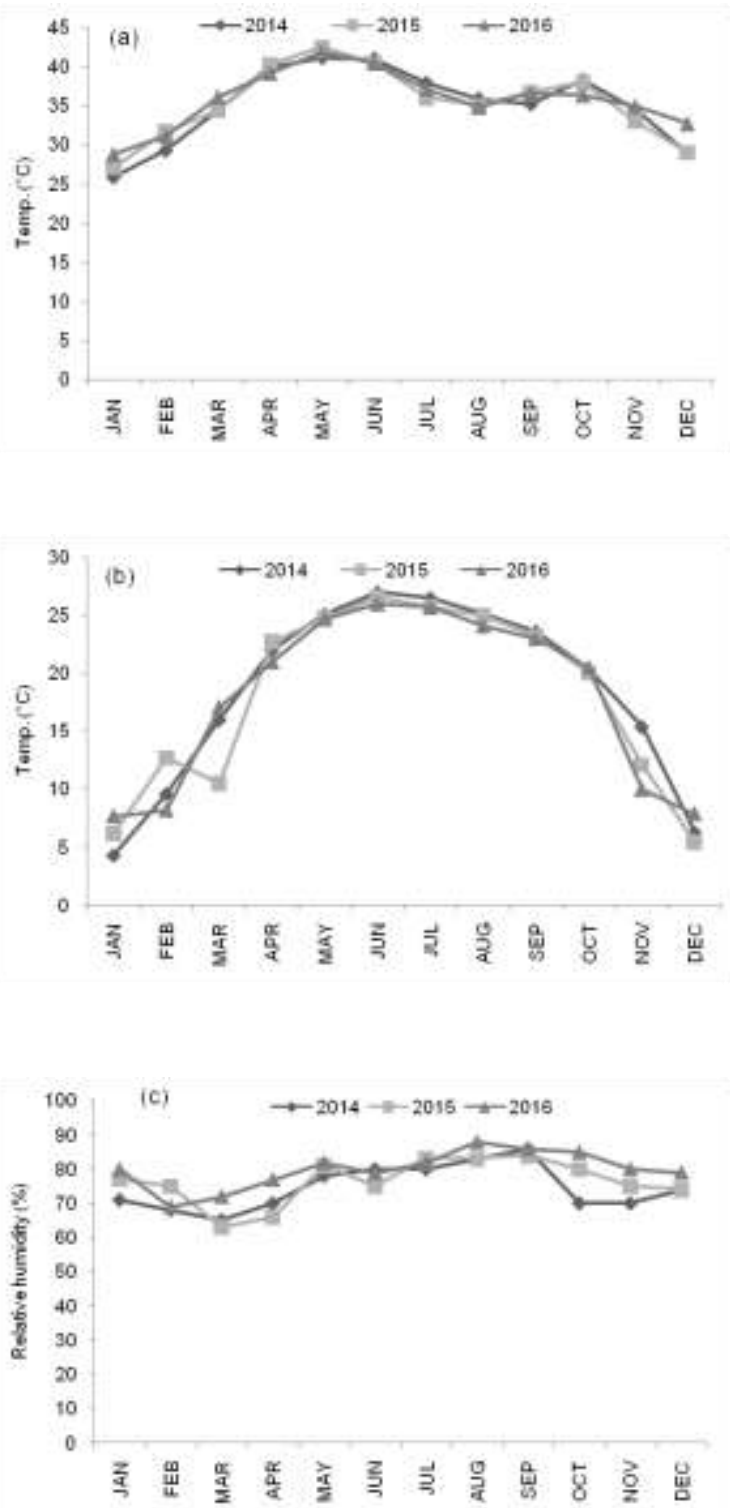

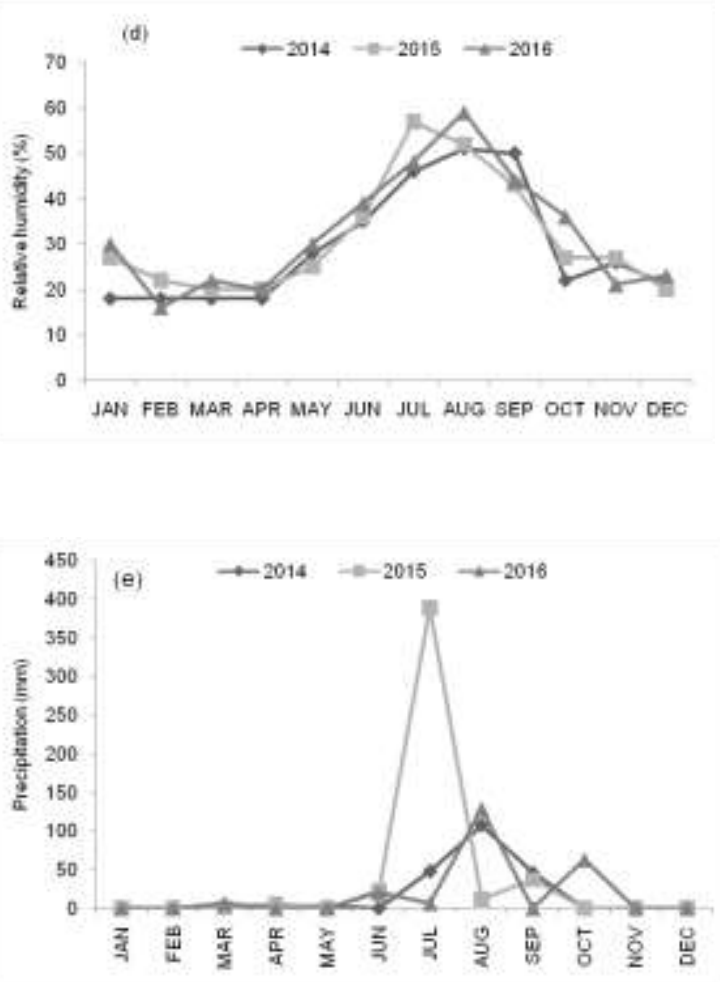

Figure 3. Mean maximum (a) and minimum (b) temperature, relative humidity at 0000 UTC (c) 1200 UTC (d) and precipitation (e) for 2014 to 2016

\section{DISCUSSION}

Ber is one of the the most important fruit trees of Thar desert, being consumed as raw and processed. It is consumed worldwide due to its nutritional composition and medicinal value (Kassem et al., 2011). These indigenous fruit species are playing an important role in conserving food security for local community (Jamnadass et al., 2011). Cultivated or wild species of jujube or ber are considered as multipurpose trees that can be grown for fruit, fodder and wood purpose. These can be considered as best vegetation for arid and semi-arid regions, which are scarce in freshwater, desertification, soil erosion and salinity are main problems.

It is necessary to prune it each year soon after fruit harvesting. This plant can withstand in harsh climate of Thar successfully, provides food in the shape of fruits, fodder in the shape of leaves and wood as fuel and shelter for humans and animals so it will be helpful to the people of Thar for malnutrition, food scarcity and climate change. Mabberley, 1997; Azam et al. (2006) reported that 86 ber species belong to genus Ziziphus (family Rhamnaceae). Luna (1996) recognized two varieties in India i.e., Var. hysudrica and Var. fruiticosa. There is a great recognized difference between wild and grafted varieties of jujube (Hocking, 1993).

From the current study it was observed that in $1^{\text {st }}$ year of fruiting season, fruit size was found small that was around $38 \mathrm{~mm}$ but with passage of time from $4^{\text {th }}$ to $5^{\text {th }}$ year when plants attained full maturity a considerable increase in fruit size was observed. Similar results for fruit weight were also recorded from a survey conducted by Islam et al. (2015). Number of main branches were also increased, that increase was from four (4) main branches in first year to eight branches in $5^{\text {th }}$ year. Similarly, all the attributes were increased with passage of time. Ber is considered as an important and locally available fruit tree in the Thar and other arid regions of Pakistan with high nutritive values. Due to its nutritious value, cheap/ low price and multipurpose uses i.e., can be consumed as fresh as well as be used after drying (Davis et al., 2006), its demand increases day by day that also raises the income of local farmers of the region even address malnutrition, nutritious fodder for their animals and sticks as fire wood for home cooking purposes.

\section{CONCLUSION}

From the current study it was observed that Ziziphus has great adaptability for the arid regions like Tharparkar in Pakistan. The Gola ber variety survived under dry climatic conditions and performed better by providing better fruit yields. So, it is important to encourage the cultivation of this ber variety under sandy desert environment of Thar and create awareness to the farmers to plant ber in this dry region.

\section{AUTHOR'S CONTRIBUTION}

A. K. Pathan: Provided technical support

M. S. Depar: Revised paper

M. W. Kalroo: Data collected

I. A. Rajput: Data analyzed

R. Ahmed: Data interpretation

\section{REFERENCES}

Azam, A. S., E. Bonkoungou, C. deKock, A. Godara and J. T. Williams. 2006. Fruits for the future 2. Southampton, UK: International Centre for Under Utilised Crops, pp. 289.

Bajwa, M. S., P. Singh and R. Singh. 1972. Ber cultivation in Punjab. Indian Horticulture, 16 (4): 12-32.

Chowdary, N. B. and N. S. Padashetty. 2000. Biochemical composition of some ber cultivars grown in North Eastern part of 
Karnataka. Current Research, University of Agriculture Science, Bangalore, 29: 99-106.

Davis, T. D., W. A. Mackay, P. Agarwal, R. Choudhary, S. Joshi, N. Sankhla and H. S. Gehlot. 2006. Ber (Ziziphus) fruits: Apple of arid regions of Indian Thar desert. $\operatorname{In}: 4^{\text {th }}$ International Conference on Managing Quality in Chains-The integrated view on fruits and vegetables quality, 712: 449-452.

Hocking, D. 1993. Trees for drylands. New Dehli, India: Oxford and IBH Publishing.

Hoque, M. A. 2002. Variabilities in ber fruits of Dhaka region. Horticulture Research Centre, Bangladesh Agricultural Research Institute, Joydebpur, Gazipur-1701, Bangladesh.

Islam, M. N., M. M. Molla, T. A. A. Nasrin, A. M. Uddin and K. Kobra. 2015. Determination of maturity indices of ber (Zizyphus mauritiana Lam.) Var. BARI Kul-2. Bangladesh Journal of Agricultural Research, 40 (1): 163-176.

Islam, M. S. 2005. Collection, evaluation and utilization of ber. Annual Report, Pomology Division, HRC.

Jamnadass, R. H., I. K. Dawson, S. Franzel. 2011. Improving livelihoods and nutrition in sub Saharan Africa through the promotion of indigenous and exotic fruit production in smallholders' agroforestry systems: A review. International Forestry Review, 13 (3): 338-354.

Jat, M. L., N. K. Gupta and G. Sunita. 2004. Fruit growth pattern and quality of contrasting ber (Zizyphus mauritiana L.) cultivars under arid environment. Journal of Eco-Physiology, 7 (3/4): 93-99.
Kassem, H. A., R. S. Al-Obeed, M. A. Ahmed and A. K. H. Omar. 2011. Productivity, fruit quality and profitability of jujube trees improvement by pre-harvest application of agro-chemicals. Middle-East Journal of Science and Research, 9 (5): 628-637.

Khushk, A. M., S. Hisbani and M. A. Ansari. 2003. Potential of jujube cultivation in Sindh. Journal of Applied Sciences, 3 (10): 627-636.

Luna, R. K. 1996. Plantation trees. Dehli, India: International Book Distributor.

Mabberley, D. J. 1997. The Plant-Book: Portable dictionary of the vascular plants. Ed. 2: xvi+ pp. 858.

Mushtaq, A., M. A. Bashir, M. A. Shakir and M. A. Khan. 2003. Performance of ber under Bahawalpur conditions. Sarhad Journal of Agriculture, 19 (1): 35-39.

Nizamani, I. A., M. A. Rustamani, S. M. Nizamani, S. A. Nizamani and M. I. Khaskheli. 2015. Population density of foliage insect pest on jujube, Ziziphus mauritiana Lam. Ecosystem. Journal of Basic and Applied Sciences, 11: 304-313.

Rahman, M. M. S., M. A. Hoque and M. M. Rahman. 2007. Evaluation of ber germplasm. Annual Report, Pomology Division, HRC.

Sarwar, M. 2006. Incidence of insect pests on ber (Zizyphus jujube) tree. Pakistan Journal of Zoology, 38 (4): 261-263.

Singh, Y. and P. Bhatnagar. 2019. An overview on inherent potential of underutilized fruits, International Journal of Pure Applied Bioscience, 7 (3): 86-103.

(Received: July 09, 2019; Accepted: June 16, 2020) 